\title{
The Impact of Structural Adjustment Programs on Foreign Direct Investments Attraction and Gold Exports in Ghana
}

\author{
Enoch Kwaw-Nimeson \\ Department of Business Administration \\ Business School \\ Hohai University \\ Jiangning Campus, Nanjing - China \\ Tian Ze \\ Head, Low Carbon Economy Research Institute \\ Hohai University \\ Changzhou Campus, Changzhou - China.
}

\begin{abstract}
Gold is the most important mineral exported in Ghana. The structural adjustment programs (SAPs) introduced in Ghana in 1986 have contributed to increased foreign direct investment attraction in Ghana. The main purpose of this study is to use cointegration approach to determine the impact of the SAPs on gold exports in Ghana. The results show real exchange rate to be significant in the long run and all of the variables to be insignificant in the short run. The study concludes that these variables have not had any significant impact on gold exports from Ghana for the period under study. The study recommends that the Government of Ghana should restructure mining sector reforms and policies that can further liberalize the investment climate to attract more foreign direct investment and also increase domestic gold sector participation in the global economy.
\end{abstract}

Keywords: SAPs, Gold exports, Gold mining sector, FDI, Trade liberalization, Cointegration

\section{Introduction}

The macroeconomic and sector specific policy reforms ${ }^{1}$ are the two most important reforms to have been introduced to the mining sector of Ghana. Ghana, just as many other undeveloped and developing countries during the 1980s and 1990s undertook several reforms and policies aimed at improving their economies and standard of living. One of such prominent reforms was the trade liberalization reforms ${ }^{2}$, made possible by major trade revolutions and policies that saw to the creation of the General Agreement on Tariffs and Trade (GATT) in 1948. GATT was subsequently replaced by the World Trade Organization (WTO), which today remains the main umbrella body for all global trade negotiations, reforms and policies.

Little et al. (1970) and Krueger (1974) were among the earliest research to discuss economic reforms and trade liberalization. Several studies have credited trade liberalization to have a positive impact on economic growth and industrialization [Greenaway et al. (1998), Krueger (1998), and Ben-David and Loewy (1998)]. The impact of trade liberalization on economic growth and industrialization by some works are inconclusive [Ocampo and Taylor (1998), Rodrik (1998), Shafaeddin (1995) and Weisbrot and Baker (2002)]. Some studies have also identified positive effects of trade liberalization on export performance [Krueger (1997); Bleaney (1999); and Ahmed (2002)], others confirmed an insignificant or even a negative relationship [Greenaway and Sapsford (1994); Jenkins (1996) and Greenaway, et al. (2002)].

There has been an upward trend in foreign direct investment (FDI $)^{3}$ inflows in Ghana since the SAPs ${ }^{4}$ were introduced in 1986 by the World Bank (WB) and the International Monetary Fund (IMF) as a response to a growing global demand for policy change to attract investments to underdeveloped and developing countries.

\footnotetext{
1 The policy framework focused mainly on public expenditure policies, trade liberalization policies, public sector management policies and state-owned enterprises reforms.

${ }^{2}$ In Ghana, these reforms dealt among others the denationalization of state-owned enterprises and scale of operations of enterprises making way for foreign acquisitions and partnerships.

${ }^{3}$ Unless otherwise stated, FDI and FDIs will be used throughout the research

${ }^{4}$ Unless otherwise stated, SAP and SAPs will be used throughout the research

104
} 
The main objective of this paper is to investigate the extent to which the SAP reforms instituted in 1986, as well as subsequent others in $2010^{5}$ and $2015^{6}$ in the mining sector, have impacted FDI attraction and gold exports.

The paper goes further to ascertain the success of the reforms in the mining sector in general by trying to answer these questions:

1. To what extent has the objectives of the SAPs in the mining sector shaped gold exports from the time it was instituted until now?

2. Has FDI inflows into the gold mining sector necessarily resulted in increases in gold exports since the institution of the SAPs?

3. Will further liberalization in the mining sector attract more investments into the mining sector of Ghana?

4. To what extent has mining sector SAPs impacted the general economic growth of Ghana?

Section two of this paper presents a concise literature review on the structure and evidence of the performance of the gold mining sector before, during and after the SAPs. Section three reviews some theoretical framework of relevant research. The methodology and materials employed in the analysis are presented in section four. Section five provides a discussion of the results. Conclusions and recommendations are provided in section six.

\section{Literature Review of Empirical Studies}

There are many facets of FDI that one has to consider when analyzing its attraction to host countries, especially to underdeveloped and developing countries. Researchershave studied some of the parameters necessary for FDI attraction. For instance, in investigating FDI in Ghana; the following researches draw these conclusions.

- FDI into the mining industry of Ghana does not depend on the size of the Ghanaian economy [(G.K. Tsikata, Asante and Gyasi (2000); Gyapong and Karikari (1999); Karikari (1992)]

- Future FDI inflows are impacted by market size, political stability, trade openness, natural resources and past FDI inflow [Anyanwu (2012); Owusu-Antwi et al. (2013);

- FDI is positively impacted on macro-economic stability [Asiedu (2006); Campos and Kinoshita, (2008)]

- FDI has a positive impact on the Ghanaian economy [Frimpong and OtengAbeyie (2008); Sackey, CompahKeyeke,andNsoah (2012)]

- Exchange rate instability has a negative impact on FDI in Ghana [(Aliber (1970), Kyereboah-Coleman and AgyireTettey (2008)]

- Inflation has a negative impact on FDI inflow in Ghana [Djokoto (2012); Djokoto and Dzeha (2012)]

A good number of other works have concentrated their research on ascertaining the determinants, influence, and capabilities of FDI in a host country. Most of these researches have concentrated on the factors stated above and others including employment, poverty reduction, infrastructural development and standard of living. However, it is reasonable to conclude that there is not one single factor that has influenced the inflow of FDI into the mining sector of Ghana. Instead, governmental policies and some specific fundamentals have been responsible for FDI attraction from time to time.

\subsection{Structure of the Gold Mining Sector in Ghana and FDI Distribution}

MNCs are the primary owners of the major mining companies in Ghana. The government and private Ghanaian investors own less than $15 \%$ of the shareholdings in these companies whereas small-scale mining (SSM) can only be operated by Ghanaians ${ }^{7}$. The main structure of the gold mining sector in Ghana is generally constituted by major ${ }^{8}$ and minor ${ }^{9}$ international companies and local ${ }^{10}$ mining companies that are into one, two or all of the following activities: mining exploration, mining production, andmine support services.

\footnotetext{
${ }^{5}$ The Mineral and Mining Law (Amendment) Act, 2010, Act (794) was introduced to reflect changing trends in international mining standards as well as address the relevant need of stakeholders

${ }^{6}$ The Mineral and Mining Law (Amendment) Act, 2015, Act (900) was introduced specifically to prescribe manner for royalties' payment, punishment for offences, payment of penalties and also details of the repeal of the Mineral and Mining (Amendment) Act, 2010, Act (794)

${ }^{7}$ The Small-Scale Gold Mining Law (1989) PNDC Law (218) was introduced to regulate the activities of SSM in Ghana. By law, only Ghanaians can own and operate small mines in Ghana.

${ }^{8}$ Goldfields Ghana Ltd, Newmont Mining Corp, Anglogold Ashanti, Chirano Gold Mine, Perseus Mineral Ltd and Asanko Gold form the majority of the major mining companies.

${ }^{9}$ Keiyong Mining, Kwalas Mining, Clearview Mines, Dani Mining, Mansoman Mining, West Coast Mining and Standfield Mining and Trading are examples of the minor mining companies.
} 
The Ministry of Land and Natural Resources (MLNR) is the main governmental body in charge of all mining activities in Ghana. It is the central body for policy formulation, adoption, and implementation. Other allied agencies such as the Minerals commission and Ghana Chamber of Mines (GCM) are responsible for the management of the shared interests of all stakeholders as well as the regulation and administration of mining activities in Ghana. Figure 1 presents a conceptual structure of the gold mining sector in Ghana.

The gold sub-sector is made up of major international mining Companies ${ }^{11}$, minor international mining companies ${ }^{12}$, and local mining companies ${ }^{13}$.

Fig. 1: Structure of the gold sub-sector of Ghana (Membership of Ghana Chamber of Mines)

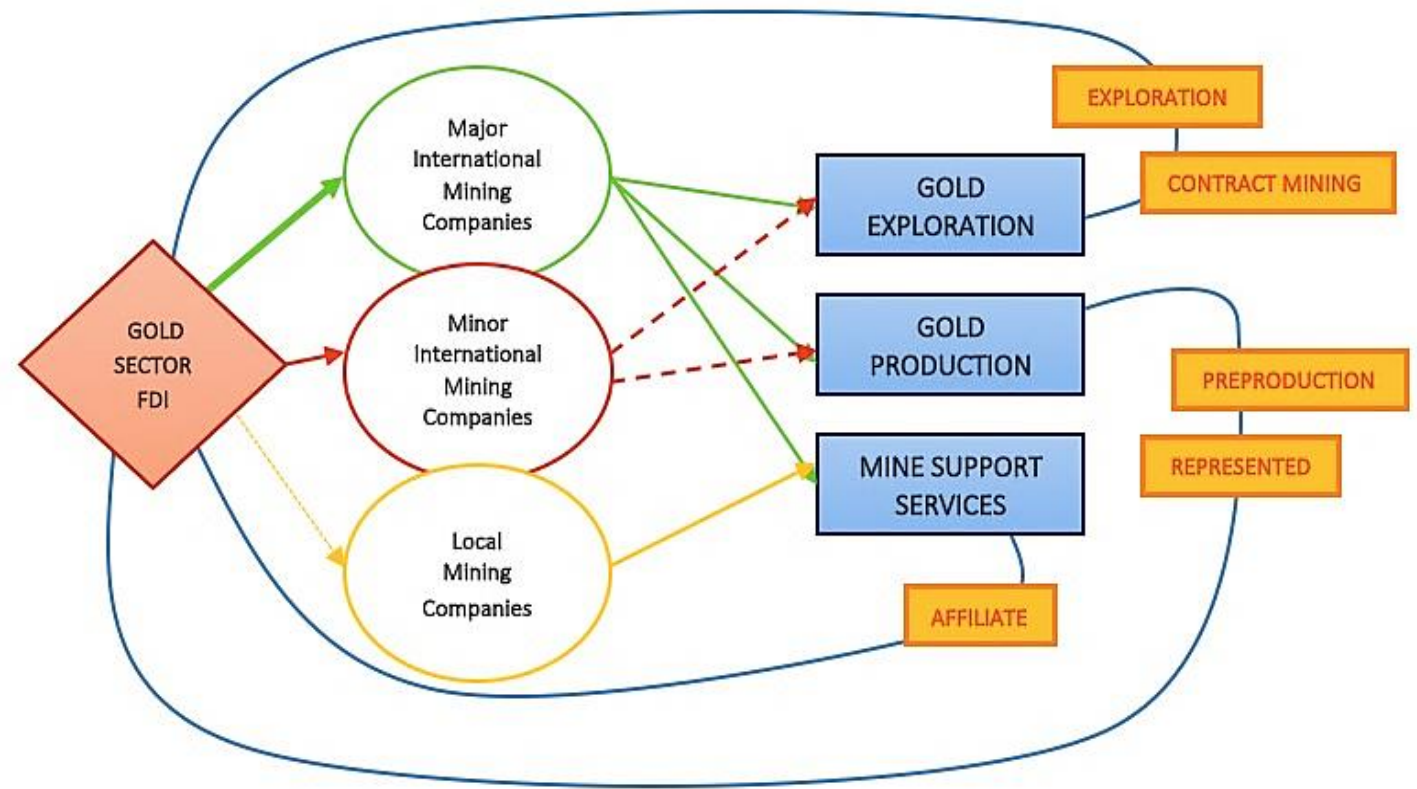

\section{Source: Authors' Analysis}

\subsection{Performance of the Gold Mining Sector}

The gold mining sector attracts the bulk (about 90\%) of all FDI in the mining sector and also attract the largest number of both large-scale and SSM operators according to the Bank of Ghana (2015). The SAPs over the last three decades have ensued in an accelerated growth in gold production and exports which have ensured the overall growth and development of the mining sector. Evidence of the SAPs in the Ghanaian economy is the growth of the economies of the towns and communities where the mines are situated. By committing to their corporate responsibilities, mining companies provide social amenities such as roads, hospitals, schools, community centers and portable drinking water to the communities where they operate.

In the first quarter of 2017, the government through the MLNR adopted the Project Appraisal and Implementation Document (PAID) that established the Multilateral Mining Integrated Project (MMIP) to enforce a ban ${ }^{14}$ on illegal SSM in Ghana. This move slightly affected gold production and exports for the 2017 gold year according to operational figure from the minerals commission.

\footnotetext{
${ }^{10}$ Consists mainly of thousands of SSM entities found across the length and breadth of mining areas, whose activities are marked by poor administration and lack of regulations

${ }^{11}$ Depicts companies that are into all the 3 phases of gold mining in Ghana - prospecting, exploration, preproduction, commercial production and contract mining services

${ }^{12}$ Depicts companies that are either into mineral exploration or production - exploration, contract mining services and commercial production

${ }^{13}$ Depicts SSM companies that are into only gold production - production

${ }^{14}$ The MMIP was constituted into components, targets, and timelines to achieve outcomes. The MMIP is expected to last until 2022

106
} 
In a story covered by the Ghana News Agency (2018), the World Bank in May 2018 pledged to support government to implement the Multi-Sectorial Integrated Mining Project (MSIMP) ${ }^{15}$ with US\$50M (US \$30M in loans and US \$20M in grants). Since the SAPs, the gold mining sector has made significant strides as it has been consistently the biggest foreign exchange earner in Ghana from 1999 till date in exception of 2004 where the sector experienced a slight fall in total revenue. In 2016, gold accounted for $26.2 \%$ of total export earnings or US $\$ 9.7 \mathrm{~B}$ or $52 \%$ of total revenue from exports.

\subsection{FDI and Exports in the $21^{\text {st }}$ Century}

Ghana exports the majority of its gold to Switzerland, the United Arab Emirates, India, China, and the Netherlands. Table 1 shows the figures for FDI, gold exports (Exports), mining sector contribution to gross domestic product $(\mathrm{GDP})^{16}$, GDP growth rate (GDPgr), the world price of gold (WP), real exchange rate (RER) and inflation rate (INFRATE) for the period under study. Reported figures from the 2016 report of the MLNR suggest that miningrelated FDI is over 50\% of Ghana's total FDI inflow and the gold mining sector FDI from 2007 to 2012 increased by $59.6 \%$ after the sector recorded a $25.96 \%$ fall in 2006 from the previous year as shown in the table. Exports volumes over the same period have grown steadily. However, with the introduction of the MMIP together with the new mining reforms instituted in 2015, it is projected that export volumes would continue to slightly decline as Governmentseeks to restructure small-scale mining and also enforce the ban on illegal SSM. Furthermore, the World Bank development indicators predict that Ghana's GDP growth rate is expected to increase to $8.3 \%$ in 2018 (it's highest in 6 years) from $6.1 \%$ in 2017 but fall again to $5.5 \%$ in 2019 and 2020 .

Table 1. FDI, Exports, GDP, GDPgr, World Price, Exchange Rate and Inflation Rate, 1987 - 2017

\begin{tabular}{|c|c|c|c|c|c|c|c|}
\hline Year & $\begin{array}{l}\text { FDI } \\
(\text { US \$M) }\end{array}$ & Exports (mt) & GDP $(\%)$ & GDP gr (\%) & $\begin{array}{l}\text { WP } \\
\text { (US \$) }\end{array}$ & $\begin{array}{l}\text { RER } \\
(\text { GHS - US \$) }\end{array}$ & $\begin{array}{l}\text { INFRATE }^{17} \\
(\%)\end{array}$ \\
\hline 1987 & 284.53 & 12.18 & 1.2 & 4.8 & 486.50 & 0.020 & 39.8 \\
\hline 1988 & 289.50 & 10.60 & 1.5 & 5.6 & 410.15 & 0.020 & 31.4 \\
\hline 1989 & 304.62 & 9.32 & 1.5 & 5.1 & 401.00 & 0.030 & 25.2 \\
\hline 1990 & 398.24 & 15.35 & 1.4 & 3.3 & 386.20 & 0.035 & 37.3 \\
\hline 1991 & 279.49 & 23.98 & 1.3 & 5.3 & 353.15 & 0.039 & 18.0 \\
\hline 1992 & 595.40 & 28.30 & 1.6 & 3.9 & 333.00 & 0.052 & 10.1 \\
\hline 1993 & 263.90 & 35.76 & 2.9 & 4.9 & 391.75 & 0.083 & 25.0 \\
\hline 1994 & 98.33 & 40.56 & 2.7 & 3.3 & 383.25 & 0.105 & 24.9 \\
\hline 1995 & 164.98 & 48.44 & 3.3 & 4.1 & 387.00 & 0.145 & 59.5 \\
\hline 1996 & 774.76 & 45.55 & 3.2 & 4.6 & 369.00 & 0.175 & 46.6 \\
\hline 1997 & 593.02 & 50.71 & 3.6 & 4.2 & 287.05 & 0.225 & 27.9 \\
\hline 1998 & 267.54 & 70.35 & 5.1 & 4.7 & 288.70 & 0.235 & 14.6 \\
\hline 1999 & 214.77 & 64.00 & 5.7 & 4.4 & 290.25 & 0.335 & 12.4 \\
\hline 2000 & 231.78 & 65.63 & 5.6 & 3.7 & 272.65 & 0.675 & 25.2 \\
\hline 2001 & 275.53 & 62.52 & 5.3 & 4.0 & 276.50 & 0.730 & 32.9 \\
\hline 2002 & 315.59 & 59.96 & 5.2 & 4.5 & 342.75 & 0.845 & 14.8 \\
\hline 2003 & 545.62 & 62.60 & 5.2 & 5.2 & 417.25 & 0.885 & 26.7 \\
\hline 2004 & 638.33 & 50.87 & 5.7 & 5.6 & 435.60 & 0.890 & 12.6 \\
\hline 2005 & 792.52 & 60.93 & 6.3 & 6.0 & 513.00 & 0.950 & 15.1 \\
\hline 2006 & 586.74 & 63.64 & 5.5 & 6.4 & 635.70 & 0.960 & 10.9 \\
\hline 2007 & 670.22 & 70.50 & 6.2 & 4.3 & 836.50 & 0.930 & 10.7 \\
\hline 2008 & 765.30 & 73.31 & 6.2 & 9.2 & 869.75 & 1.155 & 16.5 \\
\hline 2009 & 762.26 & 83.07 & 5.8 & 4.8 & 1087.50 & 1.465 & 19.3 \\
\hline 2010 & 770.01 & 84.20 & 5.6 & 7.9 & 1420.25 & 1.440 & 10.7 \\
\hline 2011 & 780.00 & 82.92 & 7.3 & 14.0 & 1531.00 & 1.535 & 8.7 \\
\hline 2012 & 1444.00 & 89.77 & 8.4 & 9.3 & 1664.00 & 1.932 & 9.2 \\
\hline 2013 & 1154.10 & 90.51 & 7.9 & 7.3 & 1204.50 & 2.150 & 11.6 \\
\hline 2014 & 950.42 & 89.80 & 7.7 & 4.0 & 1199.25 & 3.723 & 15.5 \\
\hline 2015 & 645.20 & 80.76 & 8.2 & 3.8 & 1060.00 & 3.814 & 17.1 \\
\hline 2016 & 971.75 & 79.00 & 7.3 & 3.7 & 1250.80 & 4.308 & 17.5 \\
\hline 2017 & $1131.42 *$ & 80.01 & 9.9 & 6.1 & 1257.10 & 4.522 & 13.4 \\
\hline
\end{tabular}

Source: Authors analysis based on data from various institutions

* Projected FDI value for 2017

\footnotetext{
${ }^{15}$ The MSIMP is to ensure responsible and sustainable SSM and also maximize the benefits of all stakeholders involved in SSM (Government of Ghana, traditional authorities, land owners, the communities and SSM companies)

${ }^{16}$ Mining sector contribution to GDP is used here as a proxy for gold mining sector GDP analysis since gold is the main contributor of GDP from the mining sector.

${ }^{17}$ Inflation Rate. Source: http://www.factfish.com/statistic-country/ghana/inflation\%20rate
} 


\section{Theoretical Framework}

The size, characteristics, determinants, and impact ${ }^{18}$ of FDI in a host country have been widely discussed. The trade theories of absolute advantage and comparative advantage have helped shape and inform FDI decisions by MNCs and projected impact on variables such as production, exports, and economic growth. Trade theories have as well led to the production of certain goods and services in developing countries that have opened up their economies to the global economy. Evidence suggests that comparative advantage affords countries the opportunity to expand their industrial and manufacturing sectors as a result of liberalization. In line with this is the assumption that SAPs in Ghana have improved efficiency, promoted growth and has led to the emergence of new industries as inefficient ones folded up in the 1980s and 1990s.

Neoclassical economics theory argues that capital seeks the highest return. In assessing the role of FDI in the economic growth of Kenya, they assert that given that the rate of return on investments differs from one country to another, capital holders will only seek to invest in countries where returns are higher. Cockcroft and Riddel (1991) further suggest that the security of investments, the scope, and speed of divestiture and the political economy of a country all influence future foreign capital inflow. Founded on the works of Itagaki (1981) and Cushman (1985), Denisia (2010) posits that an appreciation in a host country's currency will drive up FDI inflows and vice-versa. Blonigen and Feenstra (1997) based on Vernon's (1966) product cycle model provides compelling evidence for a substitution relationship between FDI and exports. Others such as Gu et al. (2008) and Iwatomo and Nabeshima (2012) posit a complementary relationship between FDI and exports based on an earlier work by Horst (1972).

In Ghana, numerous such complementary research has been carried out on the same subject. Some works have focused on the effects of gold mining on the environment and health of the people that live in mining areas [Akabzaa and Dramani (2001); Addai and Baiden (2014); Awudi (2002)]. Amponsah-Tawiah and Dartey-Baah (2001) offer contrasting views on FDI impact in Ghana. Antwi et al (2013), using the simple OLS regressions annual time series data on FDI and other variables covering the periods 1980 to 2010 provide evidence that FDI has a positive impact on GDP and GDP growth rate. Both Olofsdotter (1998) and Balasubramanyam et al. (1996) provides proof of a positive existential relationship between FDI and economic growth using cross-section data and OLS regressions. Lastly, Frimpong and Abaye (1996) in examining the link between FDI and GDP growth rate for the post-SAP, SAP and preSAP periods from 1970 to 2005 concluded that there is no connection between FDI and economic growth. Findings in this study, however, conclude that all things being equal, an increase in gold sector FDI is dependent on the growth of the Ghanaian Economy (measured by GDP and GDPgr)

\section{Methodology and Materials}

\subsection{Data Sources and Model Specification}

Secondary data such as article journals, books, online resources and annual statistical data from the Minerals Commission of Ghana, Ghana Chamber of Mines, Ghana Statistical Services and various institutions were used in this study. The period chosen for the study is $1987-2017$ which reflects the time series under study. The econometric software EVIEWS 9 is used for the multivariate analysis.

\section{Model Specification}

The general form of the model estimated in this study is expressed in the following form:

$Y=\alpha_{0}+\alpha_{1} X_{1}+\alpha_{2} X_{2}+\alpha_{3} X_{3}+\alpha_{4} X_{4}+\alpha_{5} X_{5}+\ldots+\alpha_{n} X_{n}$

The primary objective is to establish whether the independent variables have an on impact FDI (Y) attraction and gold exports. Here we assume that FDI is a function of the variables stated below.

$F D I=f(E X, G D P, G D P g r, W P, R E R, I N F L A T E, T L I B)$

Where,

$\mathrm{FDI}=$ dependent variable

Independent variables are:

$\mathrm{EX}=$ gold exports

GDP = percentage of overall gross domestic product from the gold mining sector

GDPgr $=$ gross domestic product growth rate of the Ghanaian economy

$\mathrm{WP}=$ world price of gold

\footnotetext{
${ }^{18}$ See Falk and Wolfmayr (2010)

108
} 
RER = real exchange rate in the study defines the value of the Ghanaian Cedi relative to the US Dollar INFRATE $=$ inflation rate, the annual growth rate of consumer price index.

TLIB $=$ the index of trade openness [(Exports + Imports)/Nominal GDP * 100] is an indication of a country's level of economic integration into the global economy.

To reduce the disparity in the variables, a natural log is employed into the model. The trade liberalization variable is used as a dummy and therefore is not in log linear form. We determined the relationship between the dependent and independent variables by regressing the following equation (equation 3 )

$$
\ln F D I_{t}=\beta_{1}+\beta_{2} \ln E X_{2}+\beta_{3} \ln G D P_{3}+\beta_{4} \ln G D P g r_{4}+\beta_{5} \ln W P_{5}+\beta_{6} \ln R E R_{6}+\beta_{7} \ln I N F L A T E_{7}+\beta_{7} T L I B_{n}+\varepsilon
$$

$\ln =$ natural $\log$

$\beta_{1} \beta_{2} \beta_{3} \beta_{4} \beta_{5} \beta_{6} \beta_{7}=$ coefficients of the independent variables

$\varepsilon=$ error term

Engle and Granger (1987) reports the existence of inaccuracies or biases in the results of time series data regressions when the data is non-stationary. To this end, we examined the time series property of the data set to test for stationarity of all the variables to determine their order of integration using the Augmented Dickey-Fuller (Dickey-Fuller, 1981) at both levels and first difference. A variable is said to be stationary when its mean and variance are constant over time. Engle and Granger (1987) further proves that an error correction model can represent the short-run disequilibrium relationship among the variables if there exists an equilibrium relationship between the variables. In estimating the short-run equilibrium relationship between the variables, they proposed a two-step methodology. The first step according to Owusu Antwi et al. (2016) is the need to establish a long-run model after a cointegration relationship between the variables has been established. The second step involves using the information on the error term in the long-run model as an added variable in the short-run model.

\section{Results and Discussions}

\subsection{Analysis of the Descriptive Statistics}

Table 2 summarizes the descriptive statistics used in this study. The average amount of FDI inflow into the mining sector for the period under study is $\$ 579.35$ million. This has been as a result of the 2010 and 2015 reforms as well as the overall increased investor confidence in the Ghanaian economy. The mean value of GDP and GDPgr are $4.98 \%$ and $5.42 \%$ respectively. These figures explain the contribution of gold sector GDP to overall GDP and overall GDP growth rate over the same period. The mean real exchange rate value of 1.11 per US dollar is explained by the depreciation of the Ghanaian Cedi against the US Dollar. World price of gold and inflation have averages of $\$ 678.75$ and $21.33 \%$ respectively.

Table 2: Descriptive Statistics

\begin{tabular}{l|rrcccr}
\hline $\begin{array}{l}\text { Variable } \\
\text { Deviation }\end{array}$ & \multicolumn{1}{l}{ Mean } & Median & Standard & Maximum & Minimum & Kurtosis \\
\hline FDI & 579.3506 & 593.0200 & 331.9102 & $1444.000 \mathrm{~B}$ & $98.33000 \mathrm{M}$ & 2.809672 \\
EX & 57.58387 & 62.60000 & 25.09869 & 90.51000 & 9.320000 & 2.223933 \\
GDP & 4.977419 & 5.500000 & 2.410769 & 9.900000 & 1.200000 & 2.223933 \\
GDPgr & 5.419355 & 4.800000 & 2.214410 & 14.00000 & 3.300000 & 8.582774 \\
WP & 678.7452 & 417.2500 & 437.0669 & 1664.000 & 272.6500 & 2.277371 \\
RER & 1.109935 & 0.845000 & 1.313404 & 4.522000 & 0.020000 & 4.113773 \\
INFRATE & 21.32581 & 17.10000 & 12.06654 & 59.50000 & 8.700000 & 4.676070 \\
Observation & 31 & 31 & 31 & 31 & 31 & 31 \\
\hline
\end{tabular}

Authors' Calculations, M - Millions (US \$), B - Billions (US \$)

\subsection{Correlation Analysis Results}

Table 3 presents the correlation matrix of the model. As expected, the dependent variable exhibits a weak relationship with the independent variables. It can be noticed that low values are reported for INFRATE. These figures suggest the possibility of finding close to zero non-significant elasticity in the next step of the analysis. 
Table 3: Correlation Analysis

\begin{tabular}{l|rrrrrrrr}
\hline Correlation & \multicolumn{1}{|c}{ FDI } & \multicolumn{1}{c}{ EX } & GDP & GDPgr & WP & RER & INFRATE & TLIB \\
\hline FDI & 1.000000 & & & & & & & \\
EX & 0.483478 & 1.000000 & & & & & & \\
GDP & 0.555628 & 0.933240 & 1.000000 & & & & & \\
GDPgr & 0.491601 & 0.257296 & 0.325531 & 1.000000 & & & & \\
WP & 0.750223 & 0.497866 & 0.577139 & 0.559099 & 1.000000 & & & \\
RER & 0.653971 & 0.907020 & 0.963441 & 0.297669 & 0.676519 & 1.000000 & & \\
INFRATE & -0.525172 & -0.516072 & -0.536453 & -0.515129 & -0.534427 & -0.544528 & 1.000000 & \\
TLIB & 0.619667 & 0.712725 & 0.809626 & 0.379914 & 0.633482 & 0.884057 & -0.524098 & 1.000000 \\
\hline
\end{tabular}

\subsection{Analysis of the Time-Series Properties of the Variables}

The Augmented Dickey-Fuller (ADF) unit root tests are used to examine the univariate time series properties of the variables. The ADF tests are conducted on all the variables besides the TLIB variable which is classified as a dummy and thus will produce a result close to a singular matrix. The critical values were tested at $1 \%, 5 \%$, and $10 \%$ significance levels. The results proved that GDP growth rate and inflation rate were significant at all levels. However, exports, GDP, world price and real exchange rate were found to be insignificant at all levels. Having to confirm that some of the variables are not stationary at levels, we were compelled to conduct a unit root test for the first difference of the data. It was noticed that the ADF test gave a significant result at first difference for all the seven variables. Table 4 presents the results of the ADF unit root test.

Table 4: Summary of ADF Unit Root Test on Variables (Levels and First Difference)

\begin{tabular}{l|lccccc}
\hline & $\begin{array}{c}\text { Critical } \\
\text { Variables }\end{array}$ & $\begin{array}{c}\text { Critical } \\
\text { Value at } \\
\mathbf{1 \%}\end{array}$ & $\begin{array}{c}\text { Critical } \\
\text { Value at } \\
\mathbf{1 0 \%}\end{array}$ & $\begin{array}{c}\text { P- } \\
\text { Value }\end{array}$ & $\begin{array}{c}\text { Test } \\
\text { Conclusion on } \\
\text { Variables }\end{array}$ \\
\hline lnFDI & -2.062765 & -3.670017 & -2.963972 & -2.621007 & 0.2602 & I $(0)$ \\
lnEX & -2.382045 & -3.670017 & -2.963972 & -2.621007 & 0.1550 & I (0) \\
lnGDP & -1.583806 & -3.670017 & -2.963972 & -2.621007 & 0.4783 & I (0) \\
lnGDPgr & -3.216573 & -3.670017 & -2.963972 & -2.621007 & 0.0288 & I (0) \\
lnWP & 0.014800 & -3.670017 & -2.963972 & -2.621007 & 0.9528 & I (0) \\
lnRER & -1.585916 & -3.670017 & -2.963972 & -2.621007 & 0.4772 & I (0) \\
lnINFRATE & -3.030256 & -3.670017 & -2.963972 & -2.621007 & 0.0434 & I (0) \\
\hline D(lnEX) & -4.237446 & -3.679322 & -2.967767 & -2.622989 & 0.0025 & I (1) \\
D(lnGDP) & -5.321473 & -3.679322 & -2.967767 & -2.622989 & 0.0002 & I (1) \\
D(lnGDPgr) & -7.801522 & -3.679322 & -2.967767 & -2.622989 & 0.0000 & I (1) \\
D(lnWP) & -3.958652 & -3.679322 & -2.967767 & -2.622989 & 0.0051 & I (1) \\
D(lnRER) & -5.000492 & -3.679322 & -2.967767 & -2.622989 & 0.0004 & I (1) \\
D(lnINFRATE) & -5.139455 & -3.711457 & -2.981038 & -2.629906 & 0.0003 & I (1) \\
\hline
\end{tabular}

\subsection{Results for Cointegration Analysis}

Having established the univariate properties of the variables, we further tested to see if any long-run relationship existed among the variables. Hence, a Johansen Cointegration test was performed to determine the cointegrating rank of the model and the number of common stochastic trends that exist among the variables. The idea behind this is to provide a strong basis for the Engel-Granger test that was performed. The results of the Johansen Cointegration test are presented in table 5. At most, there are four cointegrating vectors that can be established at a 5\% significance level among the seven variables indicated by both the Trace and Maximum Eigen value statistics. 
Table 5: Johansen Cointegration Test

Unrestricted Cointegration Rank Test (Trace)

\begin{tabular}{ccccc}
\hline \hline $\begin{array}{c}\text { Hypothesized } \\
\text { No. of CE(s) }\end{array}$ & Eigenvalue & $\begin{array}{c}\text { Trace } \\
\text { Statistic }\end{array}$ & $\begin{array}{c}0.05 \\
\text { Critical Value }\end{array}$ & Prob.** \\
\hline \hline None $*$ & 0.936823 & 205.8134 & 125.6154 & 0.0000 \\
At most 1 $*$ & 0.795361 & 125.7208 & 95.75366 & 0.0001 \\
At most 2 & 0.692021 & 79.71212 & 69.81889 & 0.0066 \\
At most 3 & 0.512482 & 45.55818 & 47.85613 & 0.0809 \\
At most 4 & 0.495981 & 24.72374 & 29.79707 & 0.1715 \\
At most 5 & 0.151464 & 4.854639 & 15.49471 & 0.8241 \\
At most 6 & 0.003154 & 0.091598 & 3.841466 & 0.7621 \\
\hline \hline
\end{tabular}

Trace test indicates 3 cointegrating eqn(s) at the 0.05 level

$*$ denotes rejection of the hypothesis at the 0.05 level

**MacKinnon-Haug-Michelis (1999) p-values

Unrestricted Cointegration Rank Test (Maximum Eigenvalue)

\begin{tabular}{ccccc}
\hline \hline $\begin{array}{c}\text { Hypothesized } \\
\text { No. of CE(s) }\end{array}$ & Eigenvalue & $\begin{array}{c}\text { Max-Eigen } \\
\text { Statistic }\end{array}$ & $\begin{array}{c}0.05 \\
\text { Critical Value }\end{array}$ & Prob.** \\
\hline \hline None $*$ & 0.936823 & 80.09258 & 46.23142 & 0.0000 \\
At most $1 *$ & 0.795361 & 46.00871 & 40.07757 & 0.0096 \\
At most 2* & 0.692021 & 34.15394 & 33.87687 & 0.0463 \\
At most 3 & 0.512482 & 20.83443 & 27.58434 & 0.2864 \\
At most 4 & 0.495981 & 19.86910 & 21.13162 & 0.0743 \\
At most 5 & 0.151464 & 4.763041 & 14.26460 & 0.7714 \\
At most 6 & 0.003154 & 0.091598 & 3.841466 & 0.7621 \\
\hline \hline
\end{tabular}

Max-eigenvalue test indicates 3 cointegrating eqn(s) at the 0.05 level

$*$ denotes rejection of the hypothesis at the 0.05 level

**MacKinnon-Haug-Michelis (1999) p-values

In order to have a full understanding of the extent of the relationship among the independent variables and the dependent variable, the long run model was assessed with the understanding of how the variables were assumed to have an effect on FDI into the gold mining sector based on the Engel-Granger methodology. The estimated long run model is given in equation 4 below:

$$
\begin{aligned}
& D(\ln F D I)=3.86-0.37 * D(\ln E X)-1.02 * D(\ln G D P)+0.63 * D(\ln G D P g r) \\
& +0.15 * D(\ln W P)+0.78 * D(\ln R E R)-0.12 * D(\ln I N F R A T E)-0.2 * T L I B
\end{aligned}
$$

Table 6 presents the results of the estimated long run equation with all seven variables. The p-value indicates that real exchange rate was significant at 5\% significance level and thus had a slight influence on FDI attraction into the gold sector during the SAPs. However, exports, GDP, GDPgr, world price, inflation rate, and trade liberalization were found to have no direct effect of FDI attraction. The long-run static equation shows that $67.98 \%$ of the independent variables can be explained by the dependent variable. Moreover, the F-statistic of 6.98 is found to be significant as the F-test was used to determine whether the regression equation explained a significantly greater amount of the FDI attraction into the gold mining sector from the SAPs period into the $21^{\text {st }}$ century. 
Table 6: Long-Run Static Equation

\begin{tabular}{lrrrr}
\hline \hline \multicolumn{1}{c}{ Variable } & Coefficient & Std. Error & t-Statistic & Prob. \\
\hline \hline C & 3.864073 & 1.462756 & 2.641638 & 0.0146 \\
LNEX & -0.365821 & 0.368681 & -0.992241 & 0.3314 \\
LNGDP & -1.015621 & 0.635096 & -1.599162 & 0.1234 \\
LNGDPGR & 0.626477 & 0.372955 & 1.679764 & 0.1065 \\
LNWP & 0.146417 & 0.263840 & 0.554949 & 0.5843 \\
LNRER & 0.779748 & 0.348825 & 2.235357 & 0.0354 \\
LNINFRATE & -0.126693 & 0.202259 & -0.626392 & 0.5372 \\
TLIB & -0.203194 & 0.184331 & -1.102333 & 0.2817 \\
\hline \hline R-squared & 0.679817 & Mean dependent var & 2.684165 \\
Adjusted R-squared & 0.582370 & S.D. dependent var & 0.280981 \\
S.E. of regression & 0.181582 & Akaike info criterion & -0.356582 \\
Sum squared resid & 0.758357 & Schwarz criterion & 0.013480 \\
Log likelihood & 13.52701 & Hannan-Quinn criter. & -0.235951 \\
F-statistic & 6.976284 & Durbin-Watson stat & 1.917745 \\
Prob(F-statistic) & 0.000165 & & \\
\hline \hline
\end{tabular}

There was a big decline in FDI inflow from 2011 - 2015 and this was as a result of investment transfer from mining to the oil and gas sector which was experiencing an exponential boom during that period. The coefficients for gold exports and gold mining sector contribution to GDP are insignificant and also have a negative sign. The coefficient for real exchange is highly significant but has a positive sign. This result ran against the expectation of the Ghanaian cedi to stabilize against the US Dollar even as international gold prices kept rising. However, the surging rates of inflation coupled with the fast depreciation of the Ghanaian Cedi since 2011 ensure that even though gold mining sector FDI is projected to increase in 2017, exports are not projected to see any significant increase. Also, the contribution of gold sector GDP to overall GDP has fallen for the same period under study.

\subsection{Results of the Vector Error Correction Model Analysis}

Haven established the existence of a cointegration relationship among the variables, we proceed to estimate the short run error correction model to assess the speed of adjustment to equilibrium by using the disequilibrium estimates from the long run model.

The estimated short-run model is presented in Equation 5 below.

$$
\begin{aligned}
& D(\ln F D I)=0.9739-0.0631 * D(\ln E X)-0.4465 * D(\ln G D P)-0.7384 * D(\ln G D P g r) \\
& -0.3071 * D(\ln W P)-0.1352 * D(\ln R E R)-1.8288 * D(\ln I N F R A T E) \\
& +0.0787 * D(T L I B)+0.8844 * D(\ln F D I(1))
\end{aligned}
$$

Table 7 below presents the results of the error correction model. The first differences and the error term from the model based on the variables as shown in the table above are represented by $D$ and $D(\operatorname{lnFDI}(1))$ respectively. Results from equation 5 show that in the short-run, the absolute t-statistic values for FDI, GDP, GDPgr, RER, and INFRATE are all greater than one. However, the p-values show that in the short run, none of the variables was significant in determining the impact of the SAPs on gold exports in Ghana during the period under study. The result of the short-run estimate is consistent with UNCTAD (2005) ${ }^{19}$ which found out that as high as $80 \%$ of FDI inflow to Africa is concentrated in the extractive sectors. More so, all the independent variables used in the study do not significantly influence the inflow of FDI into the gold sector of the mining industry in Ghana in the short run. The F-statistic indicates that the coefficients are jointly not significant at $5 \%$ since the independent variables explain about $50.85 \%$ of the variation in SAPs FDI attraction to the gold sector and their impact on exports.

\footnotetext{
${ }^{19}$ UNCTAD (2005). Economic development in Africa - Rethinking the role of foreign direct investments. New York and Geneva: United Nations
} 
Table 7: Parsimonious Short-Run Static Equation

\begin{tabular}{|c|c|c|c|c|c|c|}
\hline & Variable & Coefficient & Std. Error & T-statistic & Prob. & \multirow{17}{*}{$\mathrm{R}-$} \\
\hline & $\mathrm{D}(\operatorname{lnFDI}(1))$ & -0.880443 & 0.275388 & -3.198257 & 0.0047 & \\
\hline & $\mathrm{D}(\ln \mathrm{EX})$ & -0.063082 & 0.097383 & 0.938014 & 0.3600 & \\
\hline & $\mathrm{D}(\ln \mathrm{lnDP})$ & -0.446510 & 0.104089 & 1.018988 & 0.3210 & \\
\hline & $\mathrm{D}$ (lnGDPgr) & -0.738351 & 0.183636 & -1.440081 & 0.1661 & \\
\hline & $\mathrm{D}(\ln \mathrm{WP})$ & -0.307146 & 0.087055 & 0.832061 & 0.4157 & \\
\hline & $\mathrm{D}(\ln R E R)$ & -0.135195 & 0.106179 & 1.205764 & 0.2427 & \\
\hline & D(lnINFRATE) & -1.828774 & 0.206464 & 1.437508 & 0.1668 & \\
\hline & $\mathrm{D}(\ln \mathrm{TLIB})$ & 0.078682 & 0.305482 & 0.843135 & 0.4096 & \\
\hline & $\mathrm{C}$ & 0.040237 & 0.058958 & 0.682464 & 0.5032 & \\
\hline squared & 0.508485 & \multicolumn{2}{|c|}{ Mean dependent var } & \multicolumn{2}{|l|}{0.020413} & \\
\hline & usted R-squared & 0.275662 & \multicolumn{2}{|c|}{ S.D. dependent var } & 0.218958 & \\
\hline & of regression & 0.186351 & \multirow{2}{*}{\multicolumn{2}{|c|}{$\begin{array}{l}\text { Akaike info criterion } \\
\text { Schwarz criterion }\end{array}$}} & -0.255576 & \\
\hline & squared resid & 0.659804 & & & 0.215905 & \\
\hline & likelihood & 13.70585 & \multicolumn{2}{|c|}{ Hannan-Quinn criter. } & -0.107914 & \\
\hline & tatistic & 2.183998 & \multirow{2}{*}{\multicolumn{2}{|c|}{ Durbin-Watson stat }} & 2.179509 & \\
\hline & $b$ (F-statistic) & 0.072676 & & & & \\
\hline
\end{tabular}

\section{Conclusions and Recommendations}

\subsection{Conclusions}

This study set out to access the possible influence that the introductions of the SAPs might have had on the attraction of FDI inflow into the gold sector of Ghana, using time series data from 1987 to 2017. The studies employed the ADF test to examine the unit root properties of the variables used in the study. The study proceeded then to investigate both the long run and short run relationships that exist among the variables after they were found to have a unit root. Furthermore, we employed the Johansen Cointegration test to determine the cointegrating rank of the model as well as to establish whether there existed any long run relationship among the variables. Next, we employed the Engel-Granger two-step cointegration methodology and error correction method to assess the speed of adjustment to equilibrium.

The results of the studies conclude that real exchange rate is significant in the long run and thus influence FDI inflows positively all other things being equal. The results, however, report a negative long-run relationship between FDI and all the other variables (Exports, GDP, GDP growth rate, world price of gold, inflation rate, trade liberalization) and therefore we can conclude that even though FDI inflows increased for much of the period under study after the SAPs were introduced, the core objectives of the SAPs which included poverty alleviation, economic development and growth and improving the general standard of living of Ghanaians was not achieved.

The insignificant values reported for these variables also answers the questions as to the extent mining sector SAPs have impacted the general economic growth of Ghana. Both GDP and GDPgr reported insignificant values and this may have been as a result of the small size of the Ghanaian economy as well as the population of Ghana. The study also found trade liberalization to be insignificant in the long run implying that in spite of the firm intent of the SAPs, there are still viable lapses in instituted policies towards FDI attraction into the mining sector of Ghana. These lapses which cut across all the major sectors of the Ghanaian economy have in the long run polarized the investment climate for both local and foreign businesses resulting in a decline of the economy. In the short run, apart from real exchange rate, all the other variables were found to be insignificant. The dwindling fortunes of the Ghanaian cedi against the United States dollar increased the value of FDI inflow over the period under study and that explains the significance of real exchange rate in the short run.

The results of this research aligns with findings by Heidhues and Obare (2011), Mkandawire and Soludo (1999) and Weisbrot and Baker (2002) and other related research such as Cornia and Helleiner (1995) which have provided ample insights into why in the long run trade liberalization has a negative impact on economic growth. This result goes further to conclude that the introduction of the SAP reforms in the mining sector of Ghana which resulted in the denationalization of state-owned corporations and also led to the mass acquisitions and partnerships between StateOwned Enterprises and MNCs have to a large extent not resulted in the expected gains in the Ghanaian economy. 


\subsection{Recommendations}

The extractive industries in Ghana generally are the beneficiaries of the bulk of FDI attraction in Ghana, especially the oil and gas and mining sectors. Policies and reforms in the gold sector have been mainly directed towards pursuing higher outputs and lowering costs to attract the right kind of FDI. Most of the FDIs accrued from the SAPs in the gold mining sector is directed towards resource-seeking and market-seeking potentials, all to the detriment of domestic enterprises due to their inability to compete with MNCs for resource and market share.

The Government of Ghana should strive towards further liberalizing the trade and investment climates in Ghana that would make it possible for more domestic industrial participation in the global marketplace. This approach should be undertaken to jointly with efforts to increase sector competition.

The Government should also work to further eliminate trade barriers and seek to lower import tariffs and duties, especially on exploratory and production machinery to make Ghana more attractive for FDI. Also, this paper suggests that regional cooperation and integration of trade should be further augmented, to increase the market size in Ghana and help attract more investors currently constrained in part by the small size of the domestic market.

Lastly, the paper recommends that there should be both a political and governmental consensus with all stakeholders of governance in Ghana to formulate and adopt a framework that ensures the continuation of reforms and policies by a new government inherited from the old government. This helps to build confidence among existing investors and also make it easier to attract potential investors.

\section{References}

Little, I.M.D., Scitovsky, T., \& Scott, M. (1970). Industry and Trade in some Developing Countries. Oxford, Oxford University Press.

Krueger, A.O. (1974). The Political Economy of the Rent-Seeking Society. American Economic Review, 64(3), 291 303.

Greenaway, D., Morgan, W., \& Wright, P. (1998). Trade Reforms, Adjustments and Growth: What Does the Evidence Tell us. The Economic Journal, 108 (450), 1547 -1561, September.

Krueger, A. (1998). Why Trade Liberalisation is Good for Growth. The Economic Journal, No. 108,pp: 1513-1522, September.

Ben-David, D., \& Loewy, B.M. (1998). Free Trade, Growth and Convergence. Journal of Economic Growth, Volume 3, June, pp. 143-170.

Ocampo, J.A., \& Taylor, L. (1998). Trade Liberalisation in Developing Economies: Modest Benefits but Problems with Productivity Growth, Macro Prices, and Income Distribution. The Economic Journal, No. 108, Pp. 1523-1546, September.

Rodrik, D. (1998). Globalization, Social Conflict, and Economic Growth. Journal of Economic Perspective, Volume 6, Pp. 87-105.

Shafaeddin, S.M. (1995). The Impact of Trade Liberalization on Export and GDP, Growth in Least Developed Countries. UNCTAD Review, Pp. 1-16. United Nations, New York and Geneva

Weisbrot, M., \& Baker, D. (2002). The Relative Impact of Trade Liberalization on Developing Countries. Briefing Paper. Washington, DC, Centre for Economic and Policy Research.

Krueger, A. O. (1997) Trade Policy and Economic Development: How We Learn. American Economic Review. 87, 122.

Bleaney, M. (1999) Trade Reform, Macroeconomic Performance and Export Growth in Ten Latin American Countries, 1979-95. Journal of International Trade and Economic Development. 8:1, 89-105.

Ahmed, N. (2002) Export Response to Trade Liberalisation in Bangladesh: A Cointegration Analysis. Applied Economics. 32, 1077-1084.

Greenaway, D., \& Sapsford, D. (1994). What does Liberalisation do for Export and Growth? Weltwirtschaftliches Archiv. 130, 152-174

Jenkins, R. (1996) Trade Liberalisation and Export Performance in Bolivia. Development and Change. 27:4, 693-716.

Greenaway, D., Morgan, W., \& Wright, P. (2002) Trade Liberalisation and Growth in Developing Countries. Journal of Development Economics. 676, 229-244

Tsikata, G. K., Asante, Y., \& Gyasi, E. M. (2000). Determinants of foreign direct investment in Ghana. London:

Overseas Development Institute. Retrieved from https://www.odi.org/publications/7134-determinants-foreigndirect-investment-ghana.

Gyapong, A. O., \& Karikari, J. A. (1999). Direct foreign investment strategies and economic performance in Ghana and Ivory Coast. Journal of Economic Development, 24(1), 133-147. 
Karikari, J. A. (1992). Causality between Direct Foreign Investment and Economic Output in Ghana. Journal of Economic Development, 17(1), 7-17.

Anyanwu, J. C. (2012). Why does foreign direct investment go where it goes? New evidence from African countries. Annals of Economics and Finance, 13(2), 425-462.

Owusu-Antwi, G., Antwi, J., \& Poku, P. K. (2013). Foreign direct investment: A journey to economic growth in Ghana - Empirical evidence. International Business and Economics Research Journal, 12(5), 576-584. doi:10.19030/iber. v12i5.7832

Asiedu, E. (2006). Foreign direct investment in Africa: The role of natural resources, market size, government policy, institutions, and political instability. The World Economy, 29(1), 63-77. doi:10.1111/j.1467-9701.2006. 00758.x

Campos, N.F., \& Kinoshita, Y. (2008). Foreign direct investment and structural reforms: Evidence from Eastern Europe and Latin America (IMF Working Papers, WP/08/26). Washington, DC: IMF. Retrieved from https://www.imf.org/external/pubs/ft/wp/2008/wp0826.pdf.

Frimpong, J. M., \& Oteng-Abayie, E. F. (2008). Bivariate causality analysis between fdi inflows and economic growth in Ghana. International Research Journal of Finance and Economics, 15, 103-112.

Sackey, F. G., Compah-Keyeke, G., \& Nsoah, J. (2012). Foreign direct investment and economic growth in Ghana. Journal of Economics and Sustainable Development, 3(10), 120-133.

Aliber, R. (1970). A theory of foreign direct investment. In C. P. Kindleberger (Ed.), The international corporation: A symposium (5th ed. pp.17-34). Cambridge: MIT Press.

Kyereboah-Coleman, A., \& Agyire-Tettey, K. F. (2008). Effect of exchange-rate volatility on foreign direct investment in Sub-Saharan Africa: The case of Ghana. Journal of Risk Finance, 9(1), 52-70. doi:10.1108/15265940810842410

Djokoto, J. G. (2012). The effect of investment promotion on foreign direct investment inflow into Ghana. International Business Research, 5(3), 46-57. doi:10.5539/ibr.v5n3p46

Djokoto, J. G. \& Dzeha, G. C. (2012). Determinants and effects of foreign direct investment in Ghana - Review of literature. Developing Country Studies, 2(11/12), 25-35.

Bank of Ghana. (2015). Annual Report 2014: Accra, Ghana, p. 93. Accessed March 3, 2018, at https://www.bog.gov.gh/index.php?option=com_content\&view=article\&id=2175annual-report2014\&catid=102annual-reports\&Itemid=172.)

Ghana News Agency. (2018). Accessed on June 17, 2018, at

http://www.ghananewsagency.org/economics/world-bank-supports-sustainable-mining-project-with-us-50m-133207

Ikiara, M.M. (2003). Foreign Direct Investment (FDI), Technology Transfer, and Poverty Alleviation: Africa's Hopes and Dilemma. African Technology Policy Studies Network (ATPS) Special Paper Series No. 16, 2003, Nairobi, Kenya.

Cockcroft, L., \& Riddell, R. (1991). Foreign Direct Investment in Sub-Saharan Africa. Policy, Resources, and External Affairs. Working Paper Series 619. (Washington, D.C., World Bank)

Itagaki, T (1981). The Theory of the Multinational Firm under Exchange Rate Uncertainty. Canadian Journal of Economics 14(2): 276-297.

Cushman, D. O. (1985). Real Exchange Rate Risk, Expectations, and the Level of Direct Investment, The Review of Economics and Statistics. 67 (2): 297-308

Denisia, V. (2010). Foreign Direct Investment Theories: An Overview of the Main FDI Theories, European Journal of Interdisciplinary Studies. 2, 2010, 53-59

Blonigen, B. \& Feenstra, R. (1996). Protectionist Threats and Foreign Direct Investment. NBER Working Paper No. 5475

Gu W., Atukose T.O., \& Yuan, Y. (2008). The Contribution of Foreign Direct Investment to China's Export Performance: Evidence from Disaggregated Sectors. American Agricultural Economics Association. No 6453, $1-31$

Iwamoto, M. \& Nabeshima, K. (2012). Can FDI Promote Export Diversification and Sophistication of Host Countries? Dynamic Panel System GMM Analysis, Institute of Development Economics. No. 347, 2-8

Horst, T. (1972). Firm and Industry Determinants of the Decision to Invest Abroad: An Empirical Study, Review of Economics and Statistics. 54

Akabzaa. T. \& Darimani, A. (2001) Impact of mining sector investment in Ghana: A Study of the Tarkwa Mining Region. Third World Network. A Draft Report Prepared for SAPRI.

Addai, K. N. \& Baiden (2014), W. B., Effect of Small Scale Mining on the Environment of Tarkwa-Nsuaem Municipality of Ghana, Journal of Environmental Earth Science. 4, 73-81 
Awudi, G. B. K. (2002). The Role of Foreign Direct Investment (FDI) in the Mining Sector of Ghana and the Environment. Organization of Economic Co-operation and Development. 1-10

Amponsah-Tawiah, K. \& Dartey-Baah, K. (2011). The Mining Industry in Ghana: A Blessing or a Curse. International Journal of Business and Social Sciences. Volume 2, 62-69 [31]

Antwi, S., Atta Mills, E.F.E., Mills G.A., \& Zhao X. (2013). Impact of foreign direct investment on economic growth: Empirical evidence from Ghana, International Journal of Academic Resources, Accounting, Finance, and Management Science. 3, 18-25

Olofsdotter, K. (1998). Foreign Direct Investment, Country Capabilities, and Economic Growth. Review of World Economics, 134 (3), 534-547.

Balasubramanyam, V.N., Salisu, M. \& Dapsford, D. (1996). "Foreign Direct Investment and Growth in EP and IS Countries, Economic Journal, 106, pp. 92 - 105.

Frimpong, J.M. \& Oteng-Abeyie, E.F. (2008). Bivariate Casualty Analysis between FDI Inflows and Economic Growth in Ghana, International Research Journal of Finance and Economics, Issue 15. Accessed on December 152017 at https://mpra.ub.unimuenchen.de/351/1/MPRA_paper_351.pdf

Engle, R.F., \& Granger, C.W.J (1987). Co-integration and Error Correction: Representation, Estimation, and Testing. Econometrica. 55(2), 251-276

Dickey, D.A., \& Fuller, W.A. (1981). Likelihood Ratio Statistics for Autoregressive Time Series with a Unit Root. Journal of Econometrics. 49(4), 1057-1072

Owusu-Antwi, G., Antwi, J., Ashong, J.D., \& Owusu-Peprah, N.T. (2016). Evidence on the Co-Integration of the Determinants of Foreign Direct Investment in Ghana. Journal of Finance and Economics, Volume 4, No. 2, 2345.

Heidhues, F., \& Obare G. (2011). Lessons from Structural Adjustment Programmes and their Effects in Africa. Journal of International Agriculture 50 (2011), No. 1: 55-64 